Original Article

\title{
A review of patterns and geographical distribution of human-wildlife conflicts in Indonesia
}

\author{
Farid Rifaie*, Eko Sulistyadi, Yuli Sulistya Fitriana
}

Museum Zoologicum Bogoriense, Research Center for Biology, Indonesian Institutes of Sciences (LIPI). Jl.Raya Bogor Km 46, Bogor, West Java, Indonesia, 16911

\begin{abstract}
The unprecedented growth of human-dominated landscapes has led to population decline and the extinction of many animal species. A major paradigm shift that perceived wildlife as problem animals into threatened species that need protection triggered human-wildlife conflict studies. Although humanwildlife conflict incidences can be found globally, they have unique characteristics in each region of the world. However, little is known about the characteristics of human-wildlife conflicts in Southeast Asia, particularly Indonesia. There is a need for a comprehensive insight into human-wildlife conflict studies in Indonesia to understand past advancements and propose future priorities. This study examined the literature that provides the overall view of the human-wildlife conflict patterns in the country. The results showed that there was a comparatively small number of studies because this field was a relatively new subject in Indonesia. Furthermore, there were big gaps regarding animal species and the geographic distribution of study sites. A total of 35 species belonging to eight taxonomic groups experienced conflicts with humans. However, the studies heavily focused on three groups of animals and certain areas of the country. The predominant conflict sites were secondary forest, agroforestry, and farmlands. The conflicts in these areas unveiled the significance of local beliefs and social norms for formulating mitigation strategies.
\end{abstract}

Keywords: Biodiversity conservation, human-wildlife conflict, Indonesia, problem animals, species distribution

Received: September 15, 2021 Revised: November 9, 2021 Accepted: November 10, 2021

\section{Introduction}

Throughout history, humans coexist with wild animals in positive and negative interrelationships (Knight, 2000; Lee-Thorp et al., 2000; Woodroffe et al., 2005). The human race survived and thrived to become the most dominant species on earth due to its ancestors' ability to avoid predators, develop weapons, form social structures as protection, and develop technologies to protect crops and livestock (Nyhus, 2016). The conflict and coexistence between humans and animals have led to the extinction of many species and a severe population decline of others (Bartlett et al., 2016; Dirzo et al., 2014).

The human-wildlife conflict (HWC) study has grown exponentially in the last three decades (Davidar, 2018; Nyhus, 2016). There was a shift in paradigm that regarded wild animals as threats to human interest into apprehension for protecting threatened wildlife from extinction (Davidar, 2018). The concern is exacerbated by the unprecedented growth of the human-dominated landscape, resulting from the exponential human population growth (Nyhus, 2016). However, certain wild animal populations bounced back from the past eradication efforts and increased the chance for negative interaction with humans (Treves \& Karanth, 2003).

This study considers HWC as any incidences in which humans and wildlife compete for resources and cause harm to both humans and wildlife (M. N. Peterson

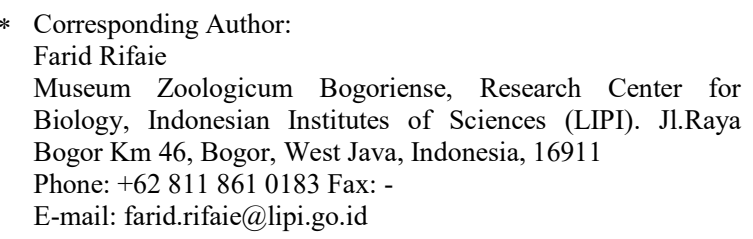

et al., 2010; Treves \& Karanth, 2003). The humanwildlife conflict is a global issue found in all continents, affecting developed and developing countries (Treves \& Karanth, 2003). HWC incidences cause adverse consequences on rural and urban inhabitants (Soulsbury \& White, 2015). People facing conflicts with wild animals experience a wide array of depredations such as crop-raiding, livestock depredations, and direct animal attacks that threaten lives and livelihood (Lamarque et al., 2009; Seoraj-Pillai \& Pillay, 2016; Snijders et al., 2019).

HWC cases have diverse characteristics in different regions because of the distinction of wild animal species and dissimilarities between farming practices typical of certain areas (Seoraj-Pillai \& Pillay, 2016). In developed countries, such as Europe and North America, HWC occurrences are mostly in areas with high human and wildlife interactions (Pack et al., 2013). It is more about wild animals' disturbance to human activities than the competition for natural resources (Towns et al., 2009). Conflicts mostly occur between large mammalian carnivores and industrial farmers (Naughton-Treves et al., 2003).

In developing countries, HWC demonstrates a broader range of depredations by problem animals. A rampant extraction of forest resources and conversion into cultivated land and high biodiversity escalated the conflicts (Treves \& Karanth, 2003). Crop-raiding by primates, herbivores, omnivores, and poultry, livestock, and human depredations by carnivores are types of conflicts in developing countries (Nyhus \& Tilson, 2004a; Sangay \& Vernes, 2008; Siljander et al., 2020). Moreover, the interaction between humans and wildlife would increase due to more overlapping resource use and 
species adaptation to live in a human-dominated landscape.

Indonesia is a Southeast Asian country with all characteristics of HWC in developing countries. The rain forests in this country are home to more than 25,000 flowering plants, equivalent to $11 \%$ of the world's flowering species (Barber et al., 2002). Also, Indonesia is home to about $10 \%$ of the world's mammals and $16 \%$ of the world's bird species (Barber et al., 2002).

Indonesian biodiversity has attracted the attention of international organizations. The World Wildlife Fund incorporated 18 ecoregions in Indonesia into their "Global 200" ecoregions (Olson \& Dinerstein, 2002). Additionally, BirdLife International recognized 24 regions in Indonesia as the Endemic Bird Areas (Stattersfield, 1998). Conservation International considered the country one of the 17 megadiverse countries, with Sundaland and Wallacea among the world's 25 biodiversity hotspots (Mittermeier, 1997; Myers et al., 2000).

Biodiversity hotspots are biogeographic regions with significant endemic species concentrations and a serious habitat loss (Myers et al., 2000). Habitat loss in Indonesia has reached an alarming rate, more than six Mha of Indonesian natural forest covers were cleared between 2000 and 2012 (Margono et al., 2014). Primary forest loss increased annually during that period, reaching $0.84 \mathrm{Mha}$ in 2012. Specifically, most deforestation occurred in Sumatra and Kalimantan Islands, where 2.8 Mha and 2.4 Mha of forested land were cleared, respectively.

More than two-fifths of the forests were converted into large-scale oil palm and timber plantations (Austin et al., 2019). Other major deforestation drivers include forests to grasslands conversion and small-scale agriculture and plantations, contributing one-fifth of nationwide forest loss, respectively. The Indonesian government tried to decelerate the forest conversion by implementing a moratorium of issuing new forest licenses for logging, oil palm, and wood-fiber plantations (President of Indonesia, 2011). Nonetheless, this policy seemed to have little effect on the rate of forest loss (Sloan, 2014; Suwarno et al., 2018).

The deforestation rate driven by smallholder farmers would possibly increase in the future. Since large-scale plantation companies increasingly comply with the moratorium, more small-scale farmers would expand their agricultural land (Kubitza et al., 2018; Mosnier et al., 2017). Initially, it was almost impossible for smallscale farmers to grow oil palm without partnering with a major company under the Nucleus Estate and Smallholder (NES) schemes (Gatto et al., 2017). However, the number of oil palm growers has significantly increased, expanding their oil palm plantations independently in the last decade (Gatto et al., 2015). They have gained knowledge and experience to grow oil palm properly, access capital, planting materials, and other inputs.

Most Indonesian islands have transmigrant and autochthonous small-scale farmers. Transmigrants are families from Java and other densely populated islands that follow the government inter-island migration program (Gatto et al., 2015). Specifically, they received titled land from the state and started growing plantation crops under a big plantation company supervision (Kubitza et al., 2018). In contrast, most autochthonous people only have customary indigenous tenure (adat) without formally recognized titles (Barkmann et al., 2010; Gatto et al., 2015). As a result, they must follow a costly and lengthy procedure to obtain formal land titles.

Farmers with no formal land titles extend their farms into adjacent forest land (Kubitza et al., 2018). The legal ambiguity between state forest land declared by the Indonesian government and land rights claims under customary law facilitate forest land appropriation to increase crop productions (Krishna et al., 2017). Moreover, the government has continuing programs to make it easier for people to get formal land titles. This could promote small-scale farmers to expand their farmlands into the forest in the future (Krishna et al., 2017).

As smallholder farmers advance their lands into the woods, the chance to encounter wild animals would increase. There have been many HWC incidence reports from various parts of the country. Nonetheless, there is no information on the number of species involved in conflicts, the intensity of conflicts, and the geographical distribution of HWC in Indonesia. Therefore, this study aimed to investigate the pattern of HWC incidences by conducting a content analysis of journal articles, reports, books, and conference presentations. It aimed to analyze the number of damage-causing animals, the pattern of conflict incidences, and the geographical distribution of HWC in Indonesia.

This study would benefit stakeholders to understand the extent of HWC studies in Indonesia by revealing the real picture of species and locations that had more research attention. Subsequently, the next studies could draw a comprehensive recommendation about target species, geographic location, and methods.

\section{Method}

\section{Literature compilation and data collation}

This study conducted a comprehensive and systematic review of the scientific literature on HWC in Indonesia. Data were collected from articles and journals containing keywords or terms related to primary HWC studies and journal reviews (Pullin \& Stewart, 2006; Seoraj-Pillai \& Pillay, 2016).

Different keyword combinations related to $\mathrm{HWC}$ in Indonesia were used to ensure high relevance for a systematic review. All the keywords were in English and Indonesian language to obtain all literature on HWC. Literature would be selected if it includes the keyword 'Indonesia' and one or more other keywords or phrases. These included human-wildlife conflict, wildlife, animal, crop depredation, crop loss, crop raiding, crop damage, livestock depredation, and livestock mortality. Other keywords and phrases were human attack, retaliatory killing, human-tiger conflict, human-elephant conflict, and human-orangutan conflict.

Google Scholar was selected for initial reference searching because it is fast, simple, and provides wide 
coverage. However, the search results are not comprehensive, vary in quality, and cannot be limited to a certain discipline. Also, further literature was explored using the following online databases bibliography: Scopus, Proquest, and Sciencedirect. It was followed by a snowball reference method to discover more literature. This protocol ensured high relevance for a literature review. 1993 was assigned as a cutoff point given the paucity of older HWC studies in Indonesia. The publications were limited to journal articles, reports, books, and conference proceedings. The analysis only considered the search results in which the study was based in Indonesia and focused on at least one wild animal species. However, studies about crop damage caused by insects and rats were excluded from the analysis. They were more related to crop pest management, where the main focus of the investigation was the lethal elimination of the problem animals.

The collected publications were compiled into a spreadsheet chronologically and analyzed under the subsequent categories: authors, year of publication,

\section{Results}

\section{Characteristics of HWC literature in Indonesia}

A total of 86 scientific publications concerning HWC in Indonesia from 1993 to 2021 were obtained. About $97 \%(n=83)$ of journal articles were published during the past two decades (2001-2020). Only one reference was published in 1993 , while $70 \%(n=60)$ of the references were published between 2011 and 2020 .

Most publications, about $78 \% \quad(n=67)$, were in English, and all 19 publications in the Indonesian language were published between 2012 and 2020 (Figure 1). Also, $56 \%(\mathrm{n}=48)$ of the HWC studies attract more attention from foreign researchers than Indonesians. Specifically, all authors of 29 papers were foreign scholars, and the first author of other 19 papers were foreigners but one or more collaborators were Indonesians. Indonesian scholars started to conduct HWC studies in 2009, with 32 publications. Moreover, there were only six publications whose first author was Indonesian, and at least one contributor was a foreign scholar.

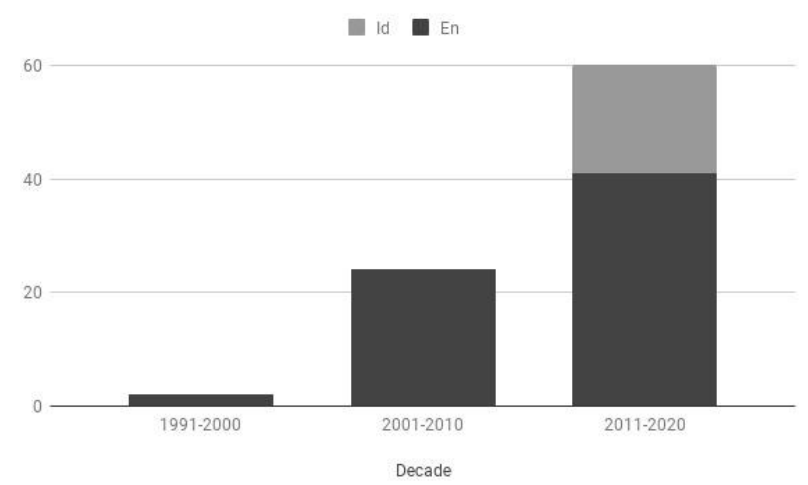

Figure 1. The number of HWC publications in Indonesia over three decades. En: the number of publications in English, Id: the number of publications in Bahasa Indonesia (Indonesian language). keywords, species, forms of conflict, casualties, location, latitude, longitude coordinates, and mitigation. A publication was only recorded as a single incident per site when it only investigated a single species or type of problem animal. Similarly, each species would be considered a separate incident per site when a publication had more than one species in their investigation.

\section{Mapping human-wildlife conflict location}

The HWC coordinates could be obtained directly from the publication when it was available. Alternatively, the geo-referencing technique was applied to derive the midpoint coordinates of the study site from Google Map. All geographical coordinates of the conflict locations were converted to decimal degree format and imported into QGIS software (QGIS Development Team, 2020). The distribution map of species-level conflict was generated from the imported coordinate data. Additionally, the provincial number of conflicts was calculated to assess changes in their incidents over time.

All publications reported the effects of HWC to people, but only 37 of them analyzed the detriments of HWC to wildlife. According to 67 publications, people only suffered one type of HWC, while 19 journal articles highlighted multiple impacts of HWC. Also, 71 publications showed crop depredation as the most common type of HWC. The second type of HWC was human injuries, shown in only 17 publications, followed by 13 articles on attacks on domestic animals, 10 on human death, and four on the destruction of buildings. Additionally, wildlife suffered three types of loss because of conflict with humans, with 30 publications mentioning death, while seven articles reported injuries and captivity.

\section{Animal species involved in conflicts}

There were 35 species from eight taxonomic groups that conflicted with humans in Indonesia as shown in Table 1. The majority of the species were mammals, with only three being birds. The largest taxonomic group was primates, whose 14 species were involved in conflicts. Additionally, $87 \%$ of the literature focused on a single animal species, while only $13 \%$ studied conflict with multiple species.

Figure 2 shows the species that attract more study interest. The Sumatran elephant (Elephas maximus sumatranus) was the most popular species, appearing in 28 publications. It was followed by long-tailed macaques (Macaca fascicularis) found in 13 publications and Sumatran Tiger (Panthera tigris sumatrae). The conflict between humans and this last remaining tiger subspecies in the Indonesian archipelago appeared in 11 journal articles. Also, orangutans, consisting of three different species (Pongo abelii, Pongo pygmaeus, and Pongo tapanuliensis) gained many interests. There were 14 publications focused on the conflict between humans and orangutans. However, the Sumatran orangutan appeared in nine publications, more than the Bornean orangutan 
mentioned four times, while the Tapanuli orangutan was reported only once.

Other species that attracted considerable study attention were Macaca ochreata brunnescens in nine publications and Macaca tonkeana in seven publications. Also, Sus scrofa was reported in seven publications, while Helarctos malayanus appeared in five papers. The eight species that appeared in only one to two scientific articles are Cacatua goffni, Cacatua sulphurea abbotti, Eos reticulata, Macaca maura, Macaca nigra, Panthera pardus melas, Bos javanicus, and Sus blouchi. The remaining 18 species were recorded due to multiple species studies that registered various problem animals in a site.

Table 1. List of animal species involved in human-wildlife conflict.

\begin{tabular}{|c|c|c|c|}
\hline Species & Common name & Species & Common name \\
\hline Aves / Birds & & Primata / Primates & \\
\hline Cacatua goffiniana & Tanimbar Corella & Macaca fascicularis & Common long-tailed Macaque \\
\hline Cacatua sulphurea & Yellow-crested Cockatoo & Macaca maura & Moor Macaque \\
\hline \multirow[t]{2}{*}{ Eos reticulata } & Blue-streaked Lory & Macaca nemestrina & Southern Pig-tailed Macaque \\
\hline & & Macaca nigra & Celebes Crested Macaque \\
\hline Carnivora / Carnivores & & Macaca brunnescens & Buton Macaque \\
\hline Panthera pardus ssp melas & Javan Leopard & Macaca tonkeana & Tonkean Macaque \\
\hline Panthera tigris ssp sumatrae & Sumatran Tiger & Presbytis rubicunda & Red Langur \\
\hline Prionailurus bengalensis & Leopard Cat & Presbytis thomasi & Thomas's Langur \\
\hline Helarctos malayanus & Sun Bear & Trachypithecus auratus & Spangled Ebony Langur \\
\hline Arctictis binturong & Bearcat/ Binturong & Trachypithecus cristatus & Silvery Lutung \\
\hline \multirow[t]{2}{*}{ Viverricula indica } & Small Indian Civet & Pongo abelii & Sumatran Orangutan \\
\hline & & Pongo pygmaeus & Bornean Orangutan \\
\hline Cetartiodactyla / Ungulates & & Pongo tapanuliensis & Tapanuli Orangutan \\
\hline Bos javanicus & Banteng & Hylobates agilis & Agile Gibbon \\
\hline Rusa unicolor & Sambar & & \\
\hline Muntiacus muntjak & Southern Red Muntjac & Pholidota / Pangolin & \\
\hline Sus barbatus & Bearded Pig & Manis javanica & Sunda Pangolin \\
\hline Sus celebensis & Sulawesi Warty Pig & & \\
\hline Sus scrofa & Wild Boar & Proboscidea / Elephant & \\
\hline Sus verrucosus & Javan Warty Pig & Elephas maximus ssp sumatranus & Sumatran Elephant \\
\hline Chiroptera / Bat & & Rodentia / Rodents & \\
\hline \multirow[t]{2}{*}{ Pteropus vampyrus } & Large Flying-fox & Hystrix brachyura & Malayan Porcupine \\
\hline & & Callosciurus notatus & Plantain Squirrel \\
\hline
\end{tabular}




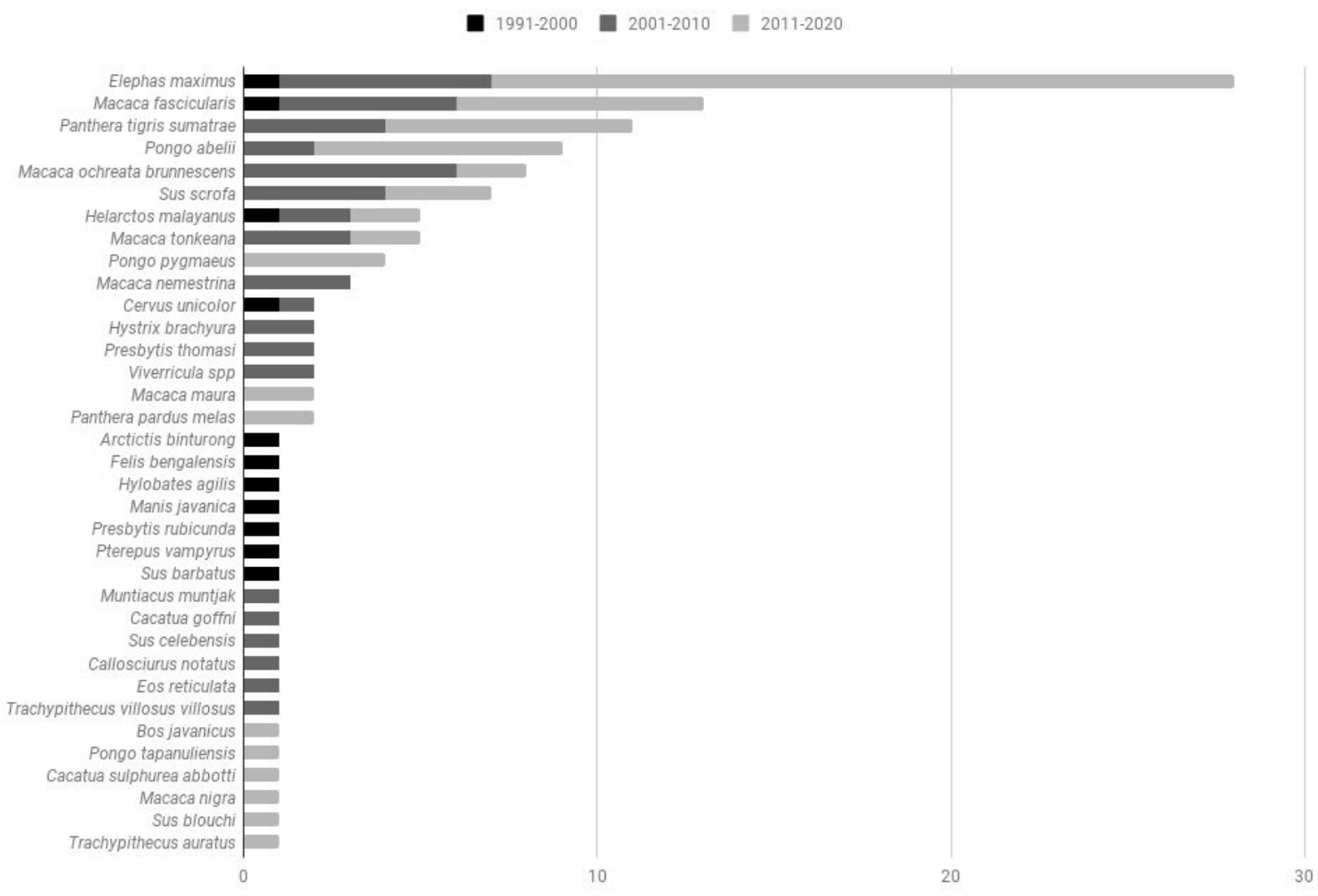

Figure 2. Number of conflict studies for each problem species in the last three decades.

\section{The distribution of HWC studies in Indonesia}

The HWC studies in Indonesia were conducted only in 23 out of 34 provinces (Figure 3). It consisted of all eight provinces of the Sumatra mainland, and four each in Kalimantan, Java, and Sulawesi Islands. There is no study which was conducted in Papua, the biggest island in Indonesia. Additionally, HWC studies were only conducted in three smaller island(s) provinces, Bali, West Nusa Tenggara, and Maluku.

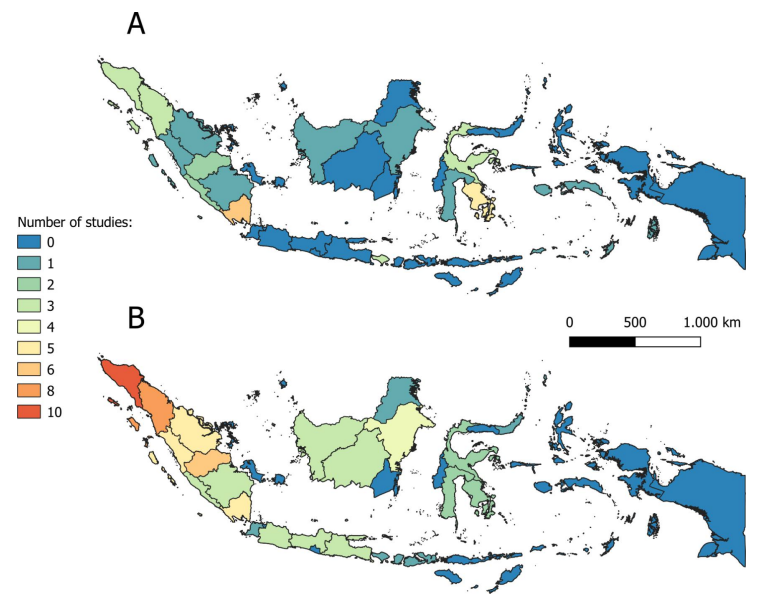

Figure 3. Geographic distribution of HWC investigations in Indonesia; A. Based on records published between 1993 and 2010; B. Based on records published between 2011 and 2020 .
The top three most reported provinces were all in Sumatra Island, including 13 cases in Aceh and 11 each in Lampung and North Sumatra. HWC studies in Aceh Province reported ten incidences of human-elephant conflicts and three on human-tiger conflicts. Similarly, nine incidences of human-elephant conflicts and three on human-tiger conflicts were reported in Lampung Province. In contrast, human-orangutan conflicts were the most dominant studies in North Sumatra Province $(n=9)$. The Other three provinces in Sumatra Island also recorded a high number of HWC publications. Jambi and West Sumatra were the study site for seven journal articles, though most of them focused on Sumatran tiger and sun bear conflicts. Riau Province recorded six HWC publications where the Sumatran elephant was the most cited animal.

Southeast Sulawesi recorded seven HWC publications, the highest among provinces outside Sumatra Island. Studies were conducted in three other provinces in Sulawesi Island, showing five studies in Central Sulawesi, three in South Sulawesi, and one in North Sulawesi. Interestingly, all HWC studies in Sulawesi were related to human-macaque conflicts. Also, the seven publications in Southeast Sulawesi studied conflicts with Button macaque (Macaca ochreata brunnescens), while the five papers in Central Sulawesi focused on conflicts with Tonkean macaque (Macaca tonkeana). Three HWC studies in South Sulawesi investigated conflicts with Moor macaque 
(Macaca maura) and Tonkean macaque. A study in North Sulawesi was related to crested black macaques (Macaca nigra).

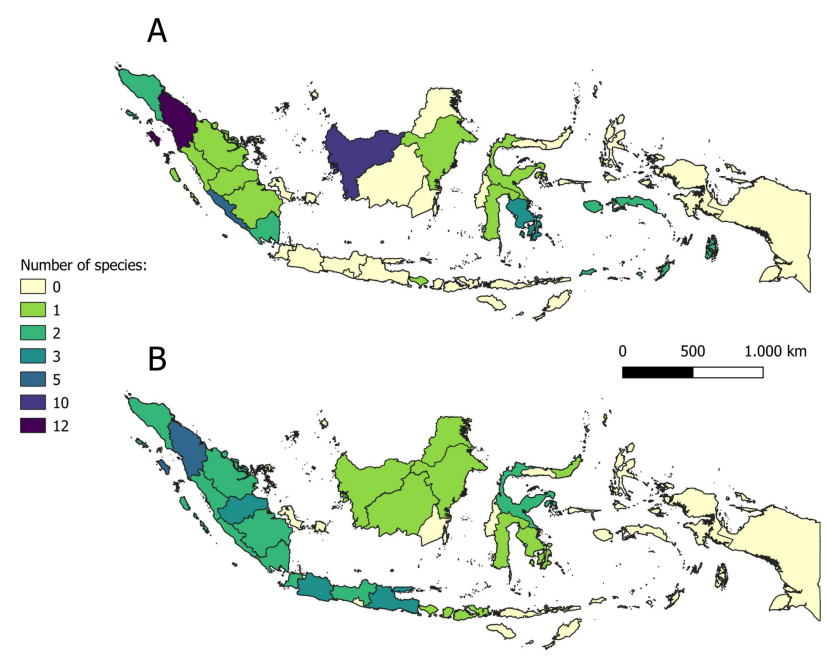

Figure 4. The number of species involved in HWC; A. Based on records published between 1993 and 2010; B. Based on records published between 2011 and 2020 .

Five HWC studies were conducted in East Kalimantan, four of which were human-orangutan conflicts and one human-sun bear conflict. Similarly, West Kalimantan became the study site of four publications, three of them which focused on humanorangutan conflicts. Furthermore, all three HWC studies in Central Kalimantan examined the human-orangutan conflicts. In contrast, North Kalimantan only had one HWC study that focused on the pygmy elephant.

Java, Bali, and Lombok Islands showed a different pattern of HWC investigations, with only five publications by foreign scholars out of the total 15. Long tailed-macaque (Macaca fascicularis) was the most popular species, appearing in ten out of 15 publications.
This species appeared in three publications in Central Java, four in Bali, and one in Banten, West Java, and Lombok Island.

Unexpectedly, Javan Leopard (Panthera pardus melas) appeared in only two publications, which both of them located in West Java. Likewise, East Java had three publications on the banteng (Bos javanicus), yellowcrested cockatoo (Cacatua sulphurea), and Bawean warty pig (Sus blouchi). Figure 4 shows the number of problem animals recorded in literature in each provinces.

As many as $45 \mathrm{HWC}$ studies in Indonesia were conducted outside protected areas (PA), with only 17 publications inside PAs. Also, 20 journal articles studied the conflict within PAs and surrounding regions.

\section{Mitigation of Human-wildlife conflict}

Conflicts between humans and wildlife incite negative perceptions toward problem animals. However, farmers recognized that there are laws that prohibit them from eradicating animals that they perceive as vermin. Consequently, they took various measures to repel wild animals or wished authorities to take some actions to solve their problems.

There were 49 publications that discussed mitigation strategies implemented by farmers or proposed by authors. The majority of literature discussed two or more approaches, with 18 publications pointing out disruptive stimuli (noise, light, or chemical deterrents) as the most popular measure. Other common efforts were building structural barriers and habitat modification, they appeared in 12 literature. People also wished management authorities to relocate the wildlife further away from their environment. Aside from that, five papers reported that communities tolerate the disturbance by wildlife so that there were no mitigation measures applied. Table 2 shows all 17 mitigation strategies mentioned in the publications.

Table 2. Types of mitigation strategies discussed or suggested in literature; C: community, E: environment, and W: wildlife.

\begin{tabular}{lcc}
\hline Mitigation strategies & Mentions in publications & Target \\
\hline Disruptive stimuli (noise, light or chemical deterrent) & 18 & W \\
Structural barriers & 12 & E \\
Habitat modification & 12 & E \\
Translocation & 9 & W \\
Community-based patrol & 8 & C \\
Guarding the field & 8 & C \\
Community outreach & C \\
Planting modification (crop selection) & 8 & E \\
Economic development of community & 7 & C \\
Buffer zone crops & 6 & E \\
Aggressive attack (throwing stones or twigs, air riffle assaults) & 5 & W \\
Agroforestry & 4 & E \\
Compensatory payments for conflicts & 3 & C \\
Community-based guarding & 2 & C \\
Early warning system & 2 & C \\
Lethal control & 2 & W \\
Collaborative management & 2 & C \\
\hline
\end{tabular}




\section{Discussion}

There are relatively few HWC studies in Indonesia, with less than 100 publications, most of which were published after 2000. Moreover, Indonesian scholars had fewer contributions than their international counterparts, and they only started to study HWC in 2009. The studies covered only 23 provinces, leaving 11 other provinces with no HWC publications.

The increase in conflict reports from various parts of the country probably reflects the high growth of interest in HWC in the last decade. However, regions with higher intensity of land cover change showed many HWC reports (Henle et al., 2008). The Sumatra Island had the highest rate of primary forest loss among other major islands (Margono et al., 2014). Between 2000 and 2012, the primary forest cover in Sumatra decreased from 16.2 Mha to 13.4 Mha, implying a $17.63 \%$ loss. Correspondingly, $57 \%$ of HWC studies were conducted on this Island, higher than other regions.

However, not all areas on this island were equally studied, with Lampung and Aceh provinces being the most popular HWC study sites in Sumatra Island. In contrast, South Sumatra was the least studied province, with only five publications. Additionally, Riau Province was first studied for HWC incidences in 2012, compared to Lampung Province in 2000. The HWC studies in Riau, Jambi, and South Sumatra provinces were mostly conducted by Indonesians.

Other regions demonstrated a similar pattern with no HWC investigation in South Kalimantan and only one study in North Kalimantan. Similarly, the HWC studies in Sulawesi Island were more concentrated in South East Sulawesi, leaving Gorontalo and West Sulawesi unexplored. Also, Java Island showed an uneven distribution of HWC study sites. Specifically, Banten province and the Special Region of Yogyakarta had little or no HWC study.

Moreover, there was a significant increase in literature from Indonesian scholars in the last decade. This brought expectations that wildlife conflict studies would reflect nationwide reality in the next few decades. The Indonesian scholars started to cover areas less attractive for foreign investigators, such as Riau, Jambi, Java Island, North Kalimantan, and North Sulawesi. Therefore, there is a need for more efforts to promote this subject to reveal the HWC trends in Indonesia.

Furthermore, only a few animal species appeared in more reports. Similar to the global trends, the predominantly reported problem wildlife were megaherbivores, large carnivores, and primates. Furthermore, the Sumatran elephant featured prominently in the HWC literature. This mega-herbivore was Sumatra's most eminent crop raider, destroyed buildings, and attacked farmers, inducing severe injury and human death. Although this critically endangered species attained more highlights than other species, most studies were conducted in Aceh and Lampung provinces. Leuser National Park, Way Kambas National Park, and Bukit Barisan Selatan National Park were the most popular spots for human-elephant conflict surveys. In comparison, few reports came from neighboring provinces such as
South Sumatra, Jambi, Riau, and North Sumatra. Similarly, the pygmy elephant in Borneo received the least attention, with only one investigation in North Kalimantan.

The animals that attained the highest publications were primates. The wide range of distribution was the major reason for high incidences of human-primates conflicts. Numerous species of primates inhabit the Indonesian Archipelago from Sumatra to the Sulawesi islands. Also, several introduced species are found in Moluccas Islands and Papua. Primates are well known for their ability to adapt to human-dominated landscapes and have diets similar to humans.

There were 14 different primates in the literature, with long-tailed macaque the most mentioned damagecausing animal among primates. Although long-tailed macaque is widely spread in Sumatra, Kalimantan, Java, and Nusa Tenggara islands, most HWC studies on this species were located in Bali and Central Java. Moreover, there were a handful of publications from Northern Sumatra, Banten, and West Kalimantan. These facts imply big gaps in Indonesia's long-tailed macaque conflicts literature, particularly from Central and Southern Sumatra, East Java, and Kalimantan. Other species belonging to the macaque genus were mostly the endemic species that live on Sulawesi Island. Buton macaque and Tonkean macaque were the two most studied macaques in Sulawesi. In contrast, Moor macaque and Celebes crested macaque received less concern from scholars.

Other primates that gained extensive features in the literature were orangutans, the only great apes native to Indonesian rainforests. Moreover, the result showed a disproportionate amount of journal articles that featured Sumatran orangutan $(P$. abelii) compared to the other two species. The number of publications on the Bornean orangutan conflict was less than half of the Sumatran orangutan, though Bornean orangutan has a wider distribution and higher population. Additionally, Kalimantan experienced a high deforestation rate, with Bornean orangutan being one of the most affected species (Freund et al., 2017; Margono et al., 2014). One possible reason for this disparity was the accessibility to the study sites. Six out of nine human-orangutan studies in Sumatra Island were conducted in Langkat District, North Sumatra. All study areas in this region were located near Bukit Lawang, a famous Sumatran orangutan sanctuary and one of the main access points to the Gunung Leuser National Park. Conversely, less accessible and less famous orangutan rehabilitation centers in Kalimantan, including Samboja, Nyaru Menteng, Tanjung Puting, and Sintang, did not attract the interest of human-orangutan conflicts studies.

Large carnivores were not the main problem animals in Indonesia, contradicting the global trend (Inskip \& Zimmermann, 2009; Sangay \& Vernes, 2008; Treves \& Karanth, 2003). The three large carnivore species reported in the literature were the Sumatran tiger, sun bear, and Javan Leopard. The Sumatran tiger is the last remaining tiger subspecies living outside Asian Continent, though their conflict cases received less recognition than the elephant and long-tailed macaque. 
Correspondingly, the sun bears found in Sumatra and Kalimantan obtained little conflict studies, while the Javan Leopard had only two publications.

The conflicts between humans and Sumatran tigers escalated because of retaliation to livestock and human attacks. Also, the escalation was caused by opportunist peasants that saw potential additional income from the sale of tiger body parts (Inskip \& Zimmermann, 2009). Human-tiger conflicts were reported from six provinces in Sumatra, while North Sumatra and Riau provinces had no human-tiger conflict study. The sun bear is an omnivore animal that raided crops, attacked livestock and humans, and damaged properties when they raided household food items. However, the low human-sun bear conflicts investigations were consistent with the global trend. There were few human-bear conflict investigations, with human-sun bear conflict being the least studied (Wong et al., 2015). In contrast, Javan Leopard received less interest despite their high removal from the wild, at a rate of 3.2 Leopards/year due to conflicts (Adhiasto et al., 2020). The Leopard was well known for its ability to exploit human-dominated environments and present perpetual risks of conflicts with humans (Seoraj-Pillai \& Pillay, 2016). Therefore, conservationists should stop neglecting these critically endangered subspecies. They should prioritize them for future HWC studies in Indonesia with a focus on developing robust mitigation systems.

The literature showed that most HWC incidents occurred outside PAs. Some of the study sites were degraded or secondary forests outside PA, where wildlife managed to survive. Moreover, several journal articles found that critically endangered species, such as orangutans, Sumatran tigers, and elephants, thrived in agroforestry landscapes. The secondary forests and agroforestry systems outside PA borders provide biological conservation and economic development values (Nyhus \& Tilson, 2004b). However, there is a need for more investigations to understand the best approaches to mitigating conflict between people and wildlife in these landscapes. Moreover, agricultural lands were other common conflict sites beyond PAs. Primates, elephants, and wild boars were the three most frequent animal groups to raid crops by transgressing the PA boundaries. Crop loss was a major reason people become intolerant toward wildlife (Gemeda \& Meles, 2018; Nyhus et al., 2000). Farmers that wanted to retain their crop yield took lethal measures by setting traps, snares, and poisons to annihilate the problem animals. Therefore, future studies should explore nonlethal methods that work best for a certain animal in a particular community. Examples include community-based crop-guarding and buffer cropping were two encouraging examples (Riley et al. 2013, Gunaryadi et al. 2017).

HWC studies inside PAs were less frequent but showed several facts that need consideration. First, farmland encroachment into PAs was common in Indonesia. This was primarily caused by the local farmers' poor awareness, indefinite PA boundaries, and insufficient law enforcement by the government (Linkie et al., 2007). Therefore, government authorities should prioritize intense PAs border enforcement to reduce illegal settlers because more conflicts occurred on their farmlands. Second, enclave villages exist inside several Indonesian PAs. In most cases, the communities had already settled inside forested areas before being designated PAs. They have limited rights to collect forest products and hold cultural conceptions that promote the conservation of their environment. However, their indigenous knowledge slowly diminished due to ineffective knowledge transfer over generations and changing sociocultural conditions of the communities (Riley, 2010).

Understanding the social landscape is a pivotal step toward developing conflict mitigation strategies (Dickman, 2010). In this regard, religions, social norms, and taboos are important values for conservation campaigns (Jones et al., 2008; St. John et al., 2018; Uyeda et al., 2016). For instance, Islam prohibits eating wild boar, animals with claws and fangs (predators), and those living on land and water bodies, including reptiles and amphibians (Mangunjaya \& McKay, 2012). Also, Islam recognized the human role as khalifa, the stewardship of all God's creations (McKay et al., 2014). On the other hand, the majority of people in Bali Island identify themselves as Hindu and recognize Tri Hita Karana, which promotes the harmonious interaction with God, people, and nature (Peterson \& Riley, 2013). They consider forests and monkeys as sacred and offer a degree of protection. Additionally, many small ethnic groups practice pagan beliefs and traditions. They live in harmony with their environment because myths, taboos, and norms control their behaviors.

Wildlife protection based on local belief was generally limited in scope and could change due to external influences. The types and extent of wildlife protections may vary between different ethnic groups even when they follow the same religion (McKay et al., 2018). In this case, local migrants having different cultures and beliefs may influence the indigenous people. The introduction of a new religion, such as Christianity, often made society abandon the taboos (Wadley et al., 1997). Therefore, future studies should explore sociocultural dynamics across Indonesia to establish strong community-based conservation.

Finally, the mitigation efforts discussed in the literature suggested that community development should become the focus of the strategy. Most of the strategies denote the community as the subject of the mitigation ( 8 out of 17 strategies). The awareness of people to coexist with wildlife and their independence to mitigate conflicts were two keys to successful campaigns. Farmers tend to perform the easiest and cheapest mitigation such as noise deterrent, building simple fences, or guarding their own farmland. Community awareness would empower them to select other non-lethal efforts to prevent wildlife raiding their farm or cattle.

The strategies implemented must empower local people so that it would be sustainable even without support from the government or NGOs. The improvement of the level of education and economic conditions of the residents were also critical to reducing behaviors that incite more conflicts such as wildlife poaching, illegal logging, and forest encroachment. 
The rehabilitation of wildlife habitat should always be included in the mitigation strategies to restrain wild animals from looking for food outside their habitat.

This review on HWC patterns in Indonesia reveals several essential points for future studies. First, there is an urgent need to speed up HWC studies because this field is relatively new. Extensive investigations of this field only started two decades ago. Therefore, it is critical to stimulate more HWC investigations to monitor all regions and more problem animals. Second, most HWC studies were conducted in Sumatra Island but heavily concentrated in Lampung and Aceh Provinces. More explorations are needed in South Sumatra, Jambi, and Riau Provinces to uncover the actual conditions of HWC in this region. Also, Kalimantan Island should become the priority area for HWC investigations because it experienced rampant forest conversions with relatively few explorations. Third, studies should be conducted on the overlooked and widely distributed problem animals. Mega-herbivore, primates, and large carnivores were the three most studied animal groups. In contrast, the last remaining large carnivore in Java Island, the Javan Leopard, was among the least studied animals. Similarly, long-tailed macaque and orangutans were poorly studied in some areas of their distribution. Fourth, non-protected secondary forests and farmlands encroaching on protected areas were Indonesia's two most prevalent HWC sites. Therefore, future studies should identify the best mitigation measures on diverse landscapes across Indonesia. Also, developing and implementing mitigation strategies must incorporate the sociocultural dynamics of each area.

\section{Acknowledgement}

The authors thank to members of Integrative Ecology and Ecosystem Services Research Group, Museum Zoologicum Bogoriense (MZB) for the constructive discussions. The first author thanks Sri Kartika Wijaya for reviewing and editing the first draft of this manuscript.

\section{References}

Adhiasto, D., Wilianto, E., \& Wibisono, H. T. (2020). Uncover the unrevealed data: The magnitude of Javan leopard removal from the wild. CATnews, 71, 5-6.

Austin, K. G., Schwantes, A., Gu, Y., \& Kasibhatla, P. S. (2019). What causes deforestation in Indonesia? Environmental Research Letters, 14(2), 024007. https://doi.org/10.1088/1748$9326 / \mathrm{aaf} 6 \mathrm{db}$

Barber, C. V., Brown, D., Matthews, E., Brown, T. H., Curran, L., \& Plume, C. (2002). State of the forest: Indonesia.

Barkmann, J., Burkard, G., Faust, H., Fremerey, M., Koch, S., \& Lanini, A. (2010). Land tenure rights, village institutions, and rainforest conversion in Central Sulawesi (Indonesia). In T. Tscharntke, C. Leuschner, E. Veldkamp, H. Faust, E. Guhardja, \& A. Bidin (Eds.), Tropical Rainforests and Agroforests under Global Change (pp. 141-160). Berlin, Heidelberg: $\quad$ Springer Berlin Heidelberg. https://doi.org/10.1007/978-3-642-00493-3_6

Bartlett, L. J., Williams, D. R., Prescott, G. W., Balmford, A., Green, R. E., Eriksson, A., Valdes, P. J., Singarayer, J. S., \& Manica, A. (2016). Robustness despite uncertainty: Regional climate data reveal the dominant role of humans in explaining global extinctions of Late Quaternary megafauna. Ecography, 39(2), $152-161$.

Davidar, P. (2018). The term human-wildlife conflict creates more problems than it resolves: Better labels should be considered. Journal of Threatened Taxa, 10(8), 12082. https://doi.org/10.11609/jott.4319.10.8.12082-12085

Dickman, A. J. (2010). Complexities of conflict: The importance of considering social factors for effectively resolving humanwildlife conflict: Social factors affecting human-wildlife conflict resolution. Animal Conservation, 13(5), 458-466. https://doi.org/10.1111/j.1469-1795.2010.00368.x

Dirzo, R., Young, H. S., Galetti, M., Ceballos, G., Isaac, N. J., \& Collen, B. (2014). Defaunation in the Anthropocene. Science, 345(6195), 401-406.

Freund, C., Rahman, E., \& Knott, C. (2017). Ten years of orangutanrelated wildlife crime investigation in West Kalimantan, Indonesia: Orangutan Trade in W. Kalimantan. American Journal of Primatology, 79(11), 22620 https://doi.org/10.1002/ajp.22620

Gatto, M., Wollni, M., Asnawi, R., \& Qaim, M. (2017). Oil Palm Boom, Contract Farming, and Rural Economic Development: Village-Level Evidence from Indonesia. World Development, 95, 127-140. https://doi.org/10.1016/j.worlddev.2017.02.013

Gatto, M., Wollni, M., \& Qaim, M. (2015). Oil palm boom and landuse dynamics in Indonesia: The role of policies and socioeconomic factors. Land Use Policy, 46, 292-303. https://doi.org/10.1016/j.landusepol.2015.03.001

Gemeda, D. O., \& Meles, S. K. (2018). Impacts of human-wildlife conflict in developing countries. Journal of Applied Sciences and Environmental Management, 22(8), 1233. https://doi.org/10.4314/jasem.v22i8.14

Gunaryadi, D., Sugiyo, \& Hedges, S. (2017). Community-based human-elephant conflict mitigation: The value of an evidencebased approach in promoting the uptake of effective methods. $\begin{array}{llll}P L O S & O N E, & 12(5), & \mathrm{e} 0173742 .\end{array}$ https://doi.org/10.1371/journal.pone.0173742

Henle, K., Alard, D., Clitherow, J., Cobb, P., Firbank, L., Kull, T., ... Young, J. (2008). Identifying and managing the conflicts between agriculture and biodiversity conservation in EuropeA review. Agriculture, Ecosystems \& Environment, 124(1-2), 60-71. https://doi.org/10.1016/j.agee.2007.09.005

Inskip, C., \& Zimmermann, A. (2009). Human-felid conflict: A review of patterns and priorities worldwide. Oryx, 43(01), 18 https://doi.org/10.1017/S003060530899030X

Jones, J. P. G., Andriamarovololona, M. M., \& Hockley, N. (2008). The Importance of Taboos and Social Norms to Conservation in Madagascar. Conservation Biology, 22(4), 976-986. JSTOR. Retrieved from JSTOR.

Knight, J. (2000). Natural enemies: People-wildlife conflicts in anthropological perspective. London: Routledge.

Krishna, V. V., Kubitza, C., Pascual, U., \& Qaim, M. (2017). Land markets, Property rights, and Deforestation: Insights from Indonesia. World Development, 99, 335-349. https://doi.org/10.1016/j.worlddev.2017.05.018

Kubitza, C., Krishna, V. V., Urban, K., Alamsyah, Z., \& Qaim, M. (2018). Land Property Rights, Agricultural Intensification, and Deforestation in Indonesia. Ecological Economics, 147, 312321. https://doi.org/10.1016/j.ecolecon.2018.01.021

Lamarque, F., Anderson, J., Fergusson, R., Lagrange, M., Osei-Owusu, Y., \& Bakker, L. (2009). Human-wildlife conflict in Africa: Causes, consequences and management strategies. Food and Agriculture Organization of the United Nations (FAO).

Lee-Thorp, J., Thackeray, J. F., \& van der Merwe, N. (2000). The hunters and the hunted revisited. Journal of Human Evolution, 39(6), 565-576. https://doi.org/10.1006/jhev.2000.0436

Linkie, M., Dinata, Y., Nofrianto, A., \& Leader-Williams, N. (2007) Patterns and perceptions of wildlife crop raiding in and around Kerinci Seblat National Park, Sumatra. Animal Conservation, 10(1), 127-135. https://doi.org/10.1111/j.14691795.2006.00083.x

Mangunjaya, F. M., \& McKay, J. E. (2012). Reviving an Islamic Approach for Environmental Conservation in Indonesia. Worldviews, $16(3), \quad 286-305$. https://doi.org/10.1163/15685357-01603006

Margono, B. A., Potapov, P. V., Turubanova, S., Stolle, F., \& Hansen, M. C. (2014). Primary forest cover loss in Indonesia over 2000-2012. Nature Climate Change, 4(8), 730-735. 
McKay, J. E., Mangunjaya, F. M., Dinata, Y., Harrop, S. R., \& Khalid, F. (2014). Practise what you preach: A faith-based approach to conservation in Indonesia. Oryx, 48(1), 23-29. https://doi.org/10.1017/S0030605313001087

McKay, J. E., St. John, F. A. V., Harihar, A., Martyr, D., LeaderWilliams, N., Milliyanawati, B., Agustin, I., Anggriawan, Y., Karlina, Kartika, E., Mangunjaya, F., Struebig, M. J., \& Linkie M. (2018). Tolerating tigers: Gaining local and spiritual perspectives on human-tiger interactions in Sumatra through rural community interviews. PLOS ONE, 13(11), e0201447. https://doi.org/10.1371/journal.pone.0201447

Mittermeier, R. A. (1997). Megadiversity: Earth's biologically wealthiest nations. Agrupacion Sierra Madre.

Mosnier, A., Boere, E., Reumann, A., Yowargana, P., Pirker, J., Havlík, P., \& Pacheco, P. (2017). Palm oil and likely futures: Assessing the potential impacts of zero deforestation commitments and a moratorium on large-scale oil palm plantations in Indonesia. Bogor: CIFOR.

Myers, N., Mittermeier, R. A., Mittermeier, C. G., da Fonseca, G. A. B. \& Kent, J. (2000). Biodiversity hotspots for conservation priorities. $\quad$ Nature, 403(6772), 853-858. https://doi.org/10.1038/35002501

Naughton-Treves, L., Grossberg, R., \& Treves, A. (2003). Paying for Tolerance: Rural Citizens' Attitudes toward Wolf Depredation and Compensation. Conservation Biology, 17(6), 1500-1511. https://doi.org/10.1111/j.1523-1739.2003.00060.x

Nyhus, P. J. (2016). Human-Wildlife Conflict and Coexistence. Annual Review of Environment and Resources, 41(1), 143-171. https://doi.org/10.1146/annurev-environ-110615-085634

Nyhus, P. J., \& Tilson, R. (2004a). Agroforestry, elephants, and tigers: Balancing conservation theory and practice in humandominated landscapes of Southeast Asia. Agriculture, Ecosystems \& Environment, 104(1), 87-97. https://doi.org/10.1016/j.agee.2004.01.009

Nyhus, P. J., \& Tilson, R. (2004b). Characterizing human-tiger conflict in Sumatra, Indonesia: Implications for conservation. Oryx, $38(01), 68-74$

Nyhus, P. J., Tilson, R., \& Sumianto, S. (2000). Crop-raiding elephants and conservation implications at Way Kambas National Park, Sumatra, Indonesia. Oryx, 34(4), 262-274.

Olson, D. M., \& Dinerstein, E. (2002). The Global 200: Priority Ecoregions for Global Conservation. Annals of the Missouri Botanical Garden, 89(2), https://doi.org/10.2307/3298564

Pack, S., Golden, R., \& Walker, A. (2013). Comparison of national wildlife management strategies: What works where, and why. Wildlife Consulting Associates, Santa Rosa, CA, USA.

Peterson, J. V., \& Riley, E. P. (2013). Monyet Yang Dihargai, Monyet Yang Dibenci: The Human-Macaque Interface in Indonesia. In S. Radhakrishna, M. A. Huffman, \& A. Sinha (Eds.), The Macaque Connection (pp. 149-166). New York, NY: Springer New York. https://doi.org/10.1007/978-1-4614-3967-7_10

Peterson, M. N., Birckhead, J. L., Leong, K., Peterson, M. J., \& Peterson, T. R. (2010). Rearticulating the myth of humanwildlife conflict. Conservation Letters, 3(2), 74-82. https://doi.org/10.1111/j.1755-263X.2010.00099.x

President of Indonesia. (2011). Instruksi Presiden Republik Indonesia Nomor 10 Tahun 2011 Tentang Penundaan Pemberian Izin Baru Dan Penyempurnaan Tata Kelol Hutan Alam Primer Dan Lahan Gambut (in Indonesian) [Instruction by the President of The Republic of Indonesia No.10 of Year 2011 Regarding The Suspension of Granting New Licenses and Improvement of Natural Primary Forest and Peatland Governance]. (Jakarta, Indonesia).

Pullin, A. S., \& Stewart, G. B. (2006). Guidelines for Systematic Review in Conservation and Environmental Management. Conservation Biology, 20(6), 1647-1656. https://doi.org/10.1111/j.1523-1739.2006.00485.x

QGIS Development Team. (2020). QGIS Geographic Information System. Open Source Geospatial Foundation Project. Retrieved from http://qgis. osgeo. org

Riley, E. P. (2010). The importance of human-macaque folklore for conservation in Lore Lindu National Park, Sulawesi, Indonesia Oryx, 44(2) 235-240. https://doi.org/10.1017/S0030605309990925

Riley, E. P., Tolbert, B., \& Farida, W. R. (2013). Nutritional content explains the attractiveness of cacao to crop raiding Tonkean macaques Current Zoology,

https://doi.org/10.1093/czoolo/59.2.160

Sangay, T., \& Vernes, K. (2008). Human-wildlife conflict in the Kingdom of Bhutan: Patterns of livestock predation by large mammalian carnivores. Biological Conservation, 141(5), 1272-1282.

Seoraj-Pillai, N., \& Pillay, N. (2016). A Meta-Analysis of HumanWildlife Conflict: South African and Global Perspectives. Sustainability, 9(1), 34. https://doi.org/10.3390/su9010034

Siljander, M., Kuronen, T., Johansson, T., Munyao, M. N., \& Pellikka, P. K. E. (2020). Primates on the farm - spatial patterns of human-wildlife conflict in forest-agricultural landscape mosaic in Taita Hills, Kenya. Applied Geography, 117, 102185. https://doi.org/10.1016/j.apgeog.2020.102185

Sloan, S. (2014). Indonesia's moratorium on new forest licenses: An update. Land Use Policy, 38, 37-40. https://doi.org/10.1016/j.landusepol.2013.10.018

Snijders, L., Greggor, A. L., Hilderink, F., \& Doran, C. (2019). Effectiveness of animal conditioning interventions in reducing human-wildlife conflict: A systematic map protocol. Environmental Evidence, $\quad 8(\mathrm{~S} 1), \quad 10$ https://doi.org/10.1186/s13750-019-0153-7

Soulsbury, C. D., \& White, P. C. L. (2015). Human-wildlife interactions in urban areas: A review of conflicts, benefits and opportunities. Wildlife Research, 42(7), 541. https://doi.org/10.1071/WR14229

St. John, F. A. V., Linkie, M., Martyr, D. J., Milliyanawati, B., McKay, J. E., Mangunjaya, F. M., ... Struebig, M. J. (2018). Intention to kill: Tolerance and illegal persecution of Sumatran tigers and sympatric species. Conservation Letters, 11(4), e12451. https://doi.org/10.1111/conl.12451

Stattersfield, A. J. (1998). Endemic bird areas of the world-Priorities for biodiversity conservation. Bird Life International.

Suwarno, A., van Noordwijk, M., Weikard, H.-P., \& Suyamto, D. (2018). Indonesia's forest conversion moratorium assessed with an agent-based model of Land-Use Change and Ecosystem Services (LUCES). Mitigation and Adaptation Strategies for Global Change, 23(2), 211-229. https://doi.org/10.1007/s11027-016-9721-0

Towns, L., Derocher, A. E., Stirling, I., Lunn, N. J., \& Hedman, D. (2009). Spatial and temporal patterns of problem polar bears in Churchill, Manitoba. Polar Biology, 32(10), 1529-1537. https://doi.org/10.1007/s00300-009-0653-y

Treves, A., \& Karanth, K. U. (2003). Human-carnivore conflict and perspectives on carnivore management worldwide. Conservation Biology, 17(6), 1491-1499.

Uyeda, L. T., Iskandar, E., Purbatrapsila, A., Pamungkas, J., Wirsing, A., \& Kyes, R. C. (2016). The role of traditional beliefs in conservation of herpetofauna in Banten, Indonesia. Oryx, 50(2), 296-301. https://doi.org/10.1017/S0030605314000623

Wadley, R. L., Colfer, C. J. P., \& Hood, I. G. (1997). Hunting Primates and Managing Forests: The Case of Iban Forest Farmers in Indonesian Borneo. Human Ecology, 25(2), 243-271. https://doi.org/10.1023/A:1021926206649

Wong, W.-M., Leader-Williams, N., \& Linkie, M. (2015). Managing Human-Sun Bear Conflict in Sumatran Agroforest Systems. Human Ecology, 43(2), 255-266. https://doi.org/10.1007/s10745-015-9729-1

Woodroffe, R., Thirgood, S., \& Rabinowitz, A. (2005). People and

wildlife, conflict or co-existence? Cambridge University Press 